\title{
The Ultimate Option for Double Cropping: Evidence from Demonstration of Chickpea (Cicer Arietinum L.) Varieties at Sayo District of Western Oromia
}

\author{
Bilisuma Kabeto*, Hika Tasfa, Demaksa Umer \\ Oromia Agricultural Research Institute (IQQO), Haro Sabu Agricultural Research Center, Haro Sebu, Ethiopia
}

Email address:

bilisak@yahoo.com (B. Kabeto)

${ }^{*}$ Corresponding author

\section{To cite this article:}

Bilisuma Kabeto, Hika Tasfa, Demaksa Umer. The Ultimate Option for Double Cropping: Evidence from Demonstration of Chickpea (Cicer Arietinum L.) Varieties at Sayo District of Western Oromia. American Journal of BioScience. Vol. 9, No. 5, 2021, pp. 162-167.

doi: $10.11648 /$ j.ajbio.20210905.12

Received: September 7, 2021; Accepted: September 7, 2021; Published: October 12, 2021

\begin{abstract}
Chick pea (Cicer Arietinum L.) is an important crop in Ethiopia and it's cropping calendar does not compete with other crops. Though it is important crop, its production is limited in certain region of the country. To hasten and expand its production, demonstration of improved varieties of kabuli type chickpea varieties was conducted in 2018/2019 under farmer management condition. Different participatory technology evaluation like pair wise ranking and direct matrix ranking were employed for participatory evaluation of varieties and the mean separation for yield was done by one-way Inova using SPSS software. The result obtained indicated significant difference of improved varieties (Arerti and Shasho) $\mathrm{P}<0.05$ compared to the local variety, and no significant difference was obtained between Arerti and Shasho. The direct matrix ranking of varieties by farmers revealed the preference of Arerti variety with $44 \%$ followed by Shasho with $41 \%$ and lastly local with $16 \%$. Besides, the evidence from pair wise ranking indicated that farmers gave more weight for grain yield, seed color, disease tolerance, early maturity, seed size, pod per plant and seed per pod respectively. More importantly, extension gap of 0.558 ton $\mathrm{ha}^{-1}$ for Shasho and 0.624 ton $\mathrm{ha}^{-1}$ for Arerti were recorded, this indicated that there is a tremendous scope of extension activities in this zone to be conducted on chickpea production and management. Generally, based on yield performance and farmers' preference, Arerti and Shasho varieties should be produced for crop diversification and double cropping in Sayo district and similar agri ecologies of Kellam Wollega zone.
\end{abstract}

Keywords: Chickpea, Demonstration, Farmer's Preference, Pairwise Ranking, Improved Varieties

\section{Introduction}

Chickpea (Cicer arietinum L.) is the second most important cool season food legume crop after common bean (Phaseolus vulgaris L.) followed by field pea (Pisum sativum) and third in production worldwide [5]. And it is considered less labor-intensive crop and its production requires fewer external inputs as compared to cereals. Ethiopia is the top ten countries of chickpea production and productivity and ranks sixth and the crop is important source of human food and animal feed crop [2]. The average chickpea yield in Ethiopia is usually below 2 ton $\mathrm{ha}^{-1}$ although its potential yield is more than 5 ton $\mathrm{ha}^{-1}$ [2]. The total cultivated area of chickpeas increased from 140,244 ha to 167,569 ha between $2002 / 03$ to $2004 / 05$, but the national average yield remains less than 1 ton $\mathrm{ha}^{-1}$ [4]. The diverse Agro climatic condition in Ethiopia makes it very suitable for growing chickpea and it is widely grown across the highland and semi-arid region of Ethiopia and serves as multipurpose crop [7].

In Oromia region of Ethiopia production of chickpea (Red and white) in 2019 was reported to be 1991783.19 quintals with average yield of 20.87 , from this production West and Kellam Wollega share nil value of chickpea production. The area is dominated by cereal and horticulture mono cropping that is produced one time or twice a year [3].

In line with this, Haro Sebu Agricultural Research Center made some efforts to address the bottleneck of farming 
communities for some crop variety on adaptation trial, regardless of its good result; farmers benefit is not as such eye-catching. Accordingly, the center was carried out adaptation trial of different Kabuli type chick pea varieties and recommended top two promising varieties. Farmer's acceptance of technology being developed is very important for enhancing the production and productivity of technology developed [14]. Therefore, participatory research and extension approach whereby stakeholders, mainly farming community actively participate in decision making and implementation from stage of problem identification through experimentation to utilization and dissemination of research results is by far crucial in addressing those problems.

The following table was taken from the result and discussion part of adaptation experiment carried out by Haro Sebu agricultural Research center in Tabor (Sayo) and Arere (Hawa Gelan) sub sites.

Table 1. Grain yield and yield components of chickpea varieties combined over location (i.e., Tabor \&Arere) of adaptation trail.

\begin{tabular}{|c|c|c|c|c|c|c|c|c|}
\hline varieties & DTF & DTM & PHT & BRPP & PPP & SPP & HSW & YLDPHQ \\
\hline Shasho & $67.2 \mathrm{a}$ & $111.8 \mathrm{~b}$ & $57.9 \mathrm{a}$ & $3.9 \mathrm{ab}$ & $59.9 a$ & $1.4 \mathrm{~b}$ & $26.0 \mathrm{c}$ & $19.8 \mathrm{a}$ \\
\hline Arerti & $63.8 \mathrm{~b}$ & $111.8 \mathrm{~b}$ & $55.6 \mathrm{a}$ & $3.4 \mathrm{~b}$ & $58.2 \mathrm{a}$ & $1.2 \mathrm{bc}$ & $28.7 \mathrm{c}$ & $20.1 \mathrm{a}$ \\
\hline Monino & $62.7 b c$ & $109.3 \mathrm{c}$ & $55.1 \mathrm{a}$ & $3.6 \mathrm{~b}$ & $37.5 \mathrm{a}$ & $1.0 \mathrm{c}$ & $48.0 \mathrm{a}$ & $5.2 \mathrm{c}$ \\
\hline Harere (local) & $62.0 \mathrm{c}$ & $110.7 \mathrm{bc}$ & $54.5 \mathrm{a}$ & $4.4 \mathrm{a}$ & $61.2 \mathrm{a}$ & $1.1 \mathrm{c}$ & $26.8 \mathrm{c}$ & $15.9 \mathrm{~b}$ \\
\hline Ejere & $64.0 \mathrm{~b}$ & $118.0 \mathrm{a}$ & $40.4 \mathrm{~b}$ & $4.0 \mathrm{ab}$ & $83.6 \mathrm{a}$ & $1.9 \mathrm{a}$ & $36.0 \mathrm{~b}$ & $13.7 \mathrm{~b}$ \\
\hline Lsd (5\%) & 1.77 & 2.5 & 6.3 & 0.82 & 55.5 & 0.3 & 4.30 & 3.66 \\
\hline $\mathrm{SE}(\mathrm{m})$ & 2.09 & 4.2 & 26.6 & 0.45 & 2054.4 & 0.06 & 12.12 & 8.96 \\
\hline
\end{tabular}

Source: [1]

$\mathrm{DTF}=$ Days to $50 \%$ Flowering, DTM $=$ Days to $90 \%$ maturity PHT $=$ Plant height, BRPS $=$ Number of primary branches per stand, PPP=pod per plant, SPP $=$ Seed per pod, HSW $=$ Hundred seed weight, YLDQ =yield per hectare $(\mathrm{Qt})$.

Based on the adaptation trial and importance of the crop to diversify crop production and enables farmers to produce twice a year in Kellam Wollega zone, this study was initiated with the following objective.

Objectives:

1) To demonstrate and evaluate the productivity of chickpea under farmers' management practices.

2) To enhance the skill and knowledge of farmers in chickpea production and management practices.

3) To boost farmers production through chick pea production after maize harvest.

\section{Materials and Methods}

\subsection{Description of the Study Area}

Sayo

Sayo district is located in the South Western part of Kellam Wollega zone. Astronomically the district is located between $8^{\circ} 12^{\prime}-8^{\circ} 44^{\prime} \mathrm{N}$ and $34^{\circ} 41^{\prime}-35^{\circ} 00^{\prime} \mathrm{E}$. The district has a total area of $127,800 \mathrm{~km}^{2}$ and generally lies within an altitudinal range of 1300-2000 masl. The major rainy seasons in the district include spring (April-may), summer (JuneAugust) and autumn (September-November).

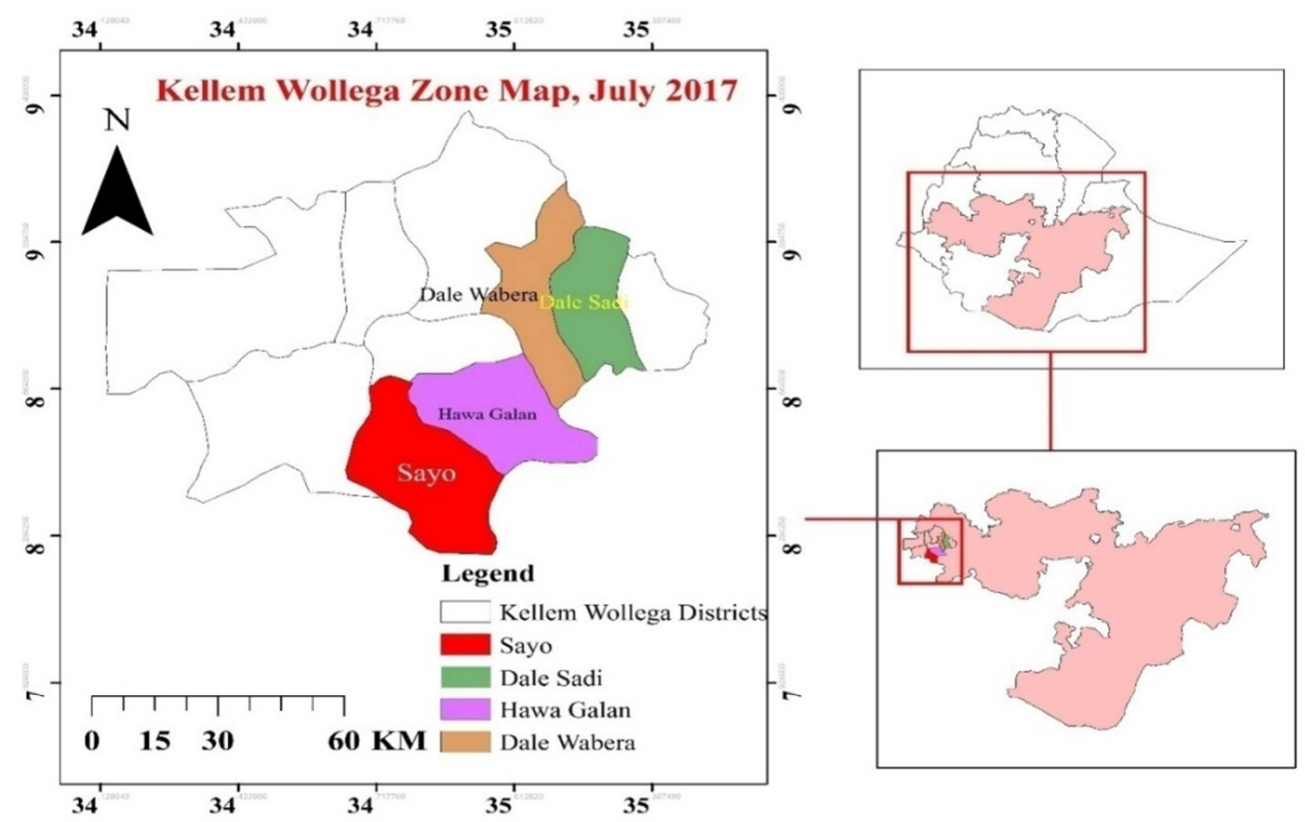

Figure 1. Geographical location of the study area. 


\subsection{Site and Farmers Selection}

One district (Sayo from Kellam Wollega Zone) was selected purposively based on chickpea production. From this district two potential peasant associations were again selected purposively based on their potential for chickpea production and accessibility. Before starting field work, formation of FRG (Farmers Research Group) were made purposively based on their representativeness of the majority of smallholder farmers, their interest and motivation in carrying out the recommended management practices (timely weeding, roughing, harvesting on time) land ownership and their commitment to deliver the technology to other farmers by considering the gender balance and other important socioeconomic variables.

Table 2. FRG member established for demonstration of chickpea.

\begin{tabular}{llllll}
\hline \multirow{2}{*}{ District } & \multirow{2}{*}{ Kebele } & \multirow{2}{*}{ Number of FRG } & Member & \multicolumn{2}{c}{ Trial farmers } \\
\cline { 3 - 6 } & & 2 & male & female & male \\
\hline \multirow{2}{*}{ Sayo } & Humbi karo & 2 & 26 & 10 & 4 \\
Total & Tabor & 4 & 54 & 12 & 5 \\
\hline
\end{tabular}

\subsubsection{Materials Used}

Two improved varieties of Chickpea, namely Shasho and Arerti as well as one local check were used for demonstration trial with participation of farmers. The recommended fertilizer rate of NPS $100 \mathrm{~kg} \mathrm{ha}^{-1}$ was used for this demonstration.

\subsubsection{Field Design}

The trial was carried out on selected farmer's fields in such a way that two improved varieties and one local check were planted side by side on equal sized non replicated plots of $10 \mathrm{~m} \times 10 \mathrm{~m}$ with a gross area of $100 \mathrm{~m}^{2}$ and replication was done across the trial farmers. Sowing was done with spacing of $40 \mathrm{~cm}$ between rows and $10 \mathrm{~cm}$ between plants.

\subsection{Technology Evaluation and Demonstration Methods}

Training and Participatory technology evaluation and selection methods were employed to demonstrate and evaluate chickpea technologies. The newly introduced and demonstrated technology was evaluated using PRA tools like Pair wise ranking, Focused group discussion \& direct matrix ranking.

\subsection{Data Type and Method of Data Analysis}

Grain yield, seed per pod, pod per plant and number of stakeholders participated on promotional event like training were objectively measured and analyzed to see the performance of varieties under farmer's management condition. The collected data were analyzed using SPSS version 22 and for illustration graph were done using sigma plot version 10 .

\section{Result and Discussion}

\subsection{Yield Performance of Demonstrated Chick Pea Varieties}

The study revealed Shasho variety superiority over other varieties with magnitude of $14.22 \mathrm{qt} \mathrm{ha}^{-1}$ followed by Arerti with magnitude of $13.86 \mathrm{qt} \mathrm{ha}^{-1}$ and Local with $9.24 \mathrm{qt} \mathrm{ha}^{-1}$.
The yield advantages of Shasho and Arerti varieties over local were $35.02 \%$ and $33.64 \%$ respectively (figure 1). [1, 11] also reported the result which concord our finding. However, there is a little difference which can be attributed to the difference in management and Agro ecology of study areas. In central part of Ethiopia, the yield of kabuli type chickpea varieties was higher according to the research conducted in three district of Kabuli production potential [13]. [12] also reported the higher yield for Arerti which was $28.6 \mathrm{qt} \mathrm{ha}^{-1}$ and [11].

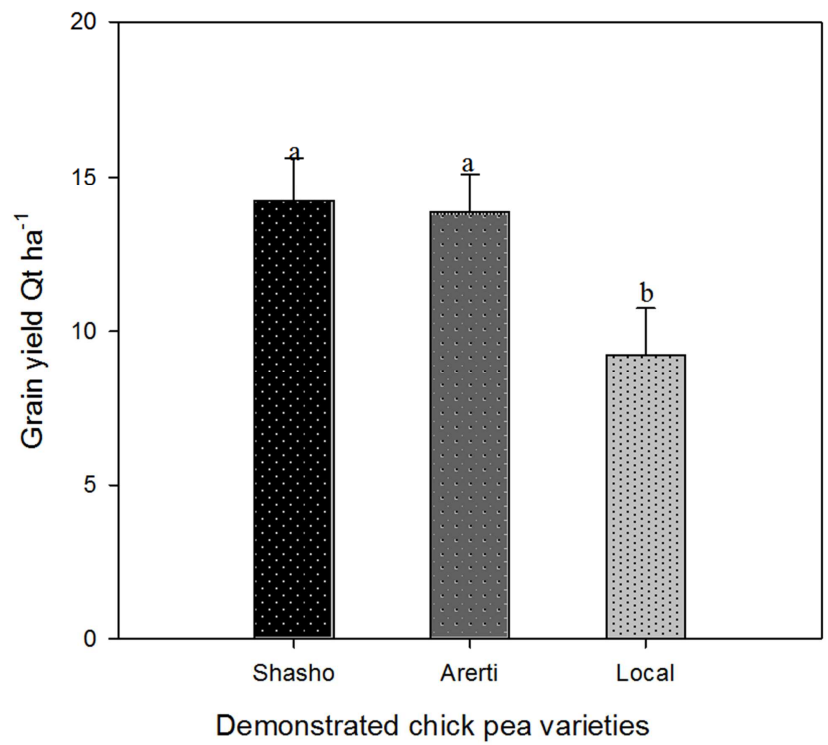

Figure 2. The yield performance of demonstrated chickpea varieties. Each value was the mean yield obtained beside each trial farmers. Different lower case indicate significate different at $(P<0.05)$.

Extension gap was calculated based on [8],

Extension gap for Shasho $=19.8-14.22=5.58 \mathrm{qt} \mathrm{ha}^{-1}$,

Extension gap for Arerti $=20.1-13.86=6.24 \mathrm{qt} \mathrm{ha}^{-1}$,

Extension gap of $5.58 \mathrm{qt} \mathrm{ha}^{-1}$ for Shasho and $6.24 \mathrm{qt} \mathrm{ha}^{-1}$ for Arerti were recorded. Similar extension gap was reported in India by study done on the front-line demonstration on chick pea with magnitude of $7.67 \mathrm{qt} \mathrm{ha}^{-1}$ [11]. This indicated that there is a tremendous scope of extension activities in this 
zone to be conducted. Mass awareness creation through print media (folder, leaflets and handbills) on Package of practices for the chickpea production and management need to be followed strictly, particularly seed rate, optimum application of nutrients, improved varieties and other management practices and there is also a need to strongly enhance the skill of public extension personal on chickpea production and management, particularly focusing on improved management of chick pea production. In Ethiopia farmer rely on own saved seed of chickpea production which reduce the productivity of the crop [13], to improve the production and productivity of chickpea, introduction of improved chickpea is ultimate solution for crop diversification and boosting farmers' income by producing chickpea after harvesting maize, one of the opportunities of chickpea production in Ethiopia is its cropping calendar does not compete with other crops creating a good opportunity for double cropping [9]. This study concord their report that chickpea production can increase farmer income by $50 \%$ and helps farmers to diversify their crop production.

\subsection{Participatory Varietal Selection, Preference and Ranking of Varieties}

Farmers have their own selection criteria and preference for new varieties which largely depend on the importance of the crop in farming system and uses [9]. Accordingly, target communities were highly inclined to their preference of demonstrated kabuli type chick pea varieties which may help them to identify which variety/varieties they prefer more and reject varieties which they prefer less. Accordingly, different stakeholders (mainly farmers, development agents, and agricultural experts) were participated on participatory evaluation and selection. In the process of participatory varietal selection and evaluation it is not only resource that could be saved but also time and fast adoption of technologies [6], thus a total of 40 participants were participated on the process at maturity stage. During the assessment farmers were assisted to list their own selection criteria which may help them to identify best varieties/variety that can fit their demand.

Table 3. Direct matrix ranking of varieties.

\begin{tabular}{lllll}
\hline \multirow{2}{*}{ No } & \multirow{2}{*}{ Criteria $(\mathbf{N}=\mathbf{4 0})$} & \multicolumn{2}{l}{ Farmers Preference and ranking of } \\
\cline { 3 - 5 } & & Shasho & Arerti & Local \\
\hline 1 & Grain yield & 25 & 15 & - \\
2 & Seed colour & 22 & 18 & - \\
3 & Seed size & 19 & 21 & - \\
4 & Pod per plant & 14 & 17 & 9 \\
5 & Seed per pod & 14 & 20 & 6 \\
6 & Marketability & 20 & 20 & - \\
7 & Early maturity & 10 & 12 & 18 \\
8 & Disease tolerance & 10 & 18 & 12 \\
& Total & 134 & 141 & 45 \\
& Percentage & $41.88 \%$ & $44.06 \%$ & $14.06 \%$ \\
& Rank & $2^{\text {nd }}$ & $1^{\text {st }}$ & $3^{\text {rd }}$ \\
\hline
\end{tabular}

The combined matrix ranking indicates that farmers selected Arerti variety as their first choice with $44.06 \%$ followed by Shasho $41.88 \%$ and the local variety was selected with lowest percentage of $14.06 \%$ (table 3 ). Arerti variety was selected as the second choice by farmers according to the research conducted by [10] on evaluation of different chickpea varieties in southern Ethiopia. The evidence from pair wise ranking indicated that farmers gave more weight for grain yield, seed color, disease tolerance, early maturity, seed size, pod per plant and seed per pod respectively (table 4). In central Ethiopia the two varieties Shasho and Arerti share $20 \%$ and $10 \%$ of farmers growing Kabuli type chickpea varieties [13].

Table 4. Pair wise ranking of varieties by farmers.

\begin{tabular}{|c|c|c|c|c|c|c|c|c|c|}
\hline Traits & GY & SC & DT & EM & SS & $\mathbf{P P}$ & SP & Frequency & Rank \\
\hline GY & $\mathrm{x}$ & GY & GY & GY & GY & GY & GY & 6 & $1^{\text {st }}$ \\
\hline $\mathrm{SC}$ & & $\mathrm{X}$ & $\mathrm{SC}$ & $\mathrm{SC}$ & $\mathrm{SC}$ & $\mathrm{SC}$ & $\mathrm{SC}$ & 5 & $2^{\text {nd }}$ \\
\hline DT & & & $X$ & DR & DR & DR & DR & 4 & $3^{\text {rd }}$ \\
\hline EM & & & & $\mathrm{X}$ & EM & EM & EM & 3 & 4 th \\
\hline SS & & & & & $\mathrm{X}$ & SS & SS & 2 & 5 th \\
\hline $\mathrm{Pp}$ & & & & & & $\mathrm{X}$ & PP & 1 & 6 th \\
\hline
\end{tabular}

$\mathrm{GY}=$ Grain yield, $\mathrm{SC}=$ Seed color, $\mathrm{DT}=$ Disease Tolerance, $\mathrm{EM}=$ Early maturity, $\mathrm{SS}=\mathrm{Seed}$ size, $\mathrm{PP}=$ Pod per plant, $\mathrm{SP}=\mathrm{Seed}$ per pod.

\subsection{Lesson Learned}

It is undeniable fact that farmers do have best indigenous knowledge of their environment and farming practice. Thus, demonstration of these Kabuli type chick pea varieties gave farmers, researchers and agricultural expert's considerable knowledge of chick pea production in different ways. Farmers aware the traits of varieties and identified the varieties which fit their demand, while researchers got farmers preference to different traits of varieties/Packages which will provide the base for future technology generation.

Chick pea is considered as bonus crop in Kenya and Tanzania [13] and farmers produce chickpea after harvesting cereals instead of leaving land fallow until next rainy season. Similarly, this study revealed that in this area it is highly possible to produce chickpea after harvesting cereals, instead of leaving land fallow until next rainy season without production. Demonstration of improved package of practice could not only increase the productivity of the crop under 
consideration, but also improve the economic status of farmers [15]. And popularization and dissemination of technology would increase the quality and chickpea production [16]. Similarly, this study revealed that production of improved chickpea varieties can increase farmers income and at the same time diversify crop production by producing twice a year in our target area.

\subsection{Training}

Practical training that focused on agronomic practices, integrated disease management and postharvest handling techniques were given to the FRG members, development agents (DA) and agricultural experts. The training sessions were aimed at facilitating and assisting farmers to apply recommended agronomic practices. A total of 107 stakeholders out of whom 37 were females and 70 males were participated on training with their percentage of $34.58 \%$ male and $65.42 \%$ of female respectively. From the training farmers got awareness on chick pea production and management.

Table 5. Training given for farmers, development agents and agricultural experts.

\begin{tabular}{lllll}
\hline District & Participant & Male & Female & Total \\
\hline \multirow{3}{*}{ Sayo } & Farmer & 50 & 28 & 78 \\
& Expert & 9 & 4 & 13 \\
Percentage & DA'S & 11 & 5 & 16 \\
\hline
\end{tabular}

\section{Conclusion and Recommendation}

The study evidenced that chickpea production in this area is an important crop for diversification and enables farmers to produce twice a year. The yield obtained from Arerti and Shasho varieties were not statistically different and Farmers also selected these two varieties with nonsignificant difference with more weight given to Arerti variety. To enhance production and Productivity of chickpea in Kellam Wollega zone, agricultural and natural resource bureau of the zone and districts should provide farmers these improved varieties of Arerti and Shasho with their full management practice, capacity building on disease management and agronomics practices is very important for improving production of chick pea production and at the same time farmers can tremendously increase their income by producing these improved varieties rather than using the local black varieties or producing cereals once a year.

\section{Declaration of Conflict of Interest}

The authors declare that they have no competing interests.

\section{Acknowledgements}

We are thankful to Agricultural Growth Program II (AGP-II) and Oromia Agricultural Research Institute
(IQQO) for financing this study for betterment of our farmer's livelihood.

\section{References}

[1] Alemu, B., Abera, D., \& Adugna, A. (2014). Adaptation Study of Improved Kabuli Chickpea (Cicer Arietinum L) Varieties at Kellem Wollega Zone, Haro Sabu, Ethiopia. 4 (18), 21-25.

[2] Asrat, Z. (2017). Significance and management of chickpea wilt/root rot and future prospects in Ethiopia. A review. International Journal of Life Sciences, 5 (1), 117-126.

[3] CSA, (2018/19). Agricultural sample survey. Report on area and production of major crops. Volume I, VII and VIII. Statistical Bulletin, I, 578.

[4] CSA. (2014). The Federal Democratic Republic of Ethiopia Central Statistical Agency Agricultural Sample Survey. Report on Area and Production of Crops Statistical Bulletin No. 586. Addis Abeba, Ethiopia.

[5] Diapari, M., Sindhu, A., Bett, K., Deokar, A., Warkentin, T. D., Taran, B., \& Francki, M. (2014). Genetic diversity and association mapping of iron and zinc concentrations in chickpea (Cicer arietinum L.). Genome, 57 (8), 459-468. https://doi.org/10.1139/gen-2014-0108

[6] Godoe, P., \& Johansen, T. S. (2012). Understanding adoption of new technologies: Technology readiness and technology acceptance as an integrated concept. Journal of European Psychology Students, 3, 38. https://doi.org/10.5334/jeps.aq

[7] Negussie Siyum Muluneh, (2018). Pre Scaling up of Chickpea Technologies at Dawa Chefa District. 1, 113-115. https://doi.org/10.31031/NTNF.2018.01.000524

[8] Singh, S., Sahu, A., and Kumari, (2019). Impact of Front Line Demonstration on Vegetable Pea Yield Improvement in Eastern Uttar Pradesh. Journal of AgriSearch, 6 (02), 173179. https://doi.org/10.21921/jas.v6i02.15760

[9] Chris O. Ojiewo, (2016). Chickpea production, technology adoption and market linkage in Ethiopia, Pan African green leagume and world cow conference, Livingstone Zambia.

[10] Abebe G., Aseffa, T., Mesfin T., Al-tawaha, AM., (2005). Participtory selection of drough tolerance maize varieties using mother baby technology: Case study in the semei arid zone of the centarl rift valley of Ethiopia, World Journal agricultural science 1: 22-27.

[11] Rajpoot, S, K, S. (2017). Evaluation of Front Line Demonstration on Chick Pea in Shajapur District of MP. Int $J$ Pure Appl Biosci. 5 (5): 293-297. doi: 10.18782/23207051.5216.

[12] Yasin G. (2014). Evaluation of Chick Pea (Cicerarietinum L.) Varieties for Yield Performance and Adaptability to Southern Ethiopia. J Biol Agric Healthc. 4 (17): 34-39.

[13] Rao N, Silim SN, Simtowe F, et al. Enhancing Chickpea Productivity and Production in Eastern and Southern Africa. Trop Legum II Proj. 2009; (January): 177-190.

[14] CGIAR, (2001). Assessing the impact of participatory research and gender analsys/edit by Nina Lilja, Jacqualine A, Ashby and louise sperling. Inetrnational center for tropical agriculture $294 \mathrm{p}$. 
[15] Kumar, R., Kushwah, R, S., Singh, S, K., Sharma, U, C., Bhadauria, N, S., Tomar, R, P, S., Kendra, K, V (2020). Evaluation of chickpea varieites under frotline demostartion at farrmers field in Bhind district of M.P. Interbnational journal of agricultural science 16 (2) 244-248.

[16] Chichaybelu, M., Girma, N., Fikre, A., Gemechu, B., Mekuria,
T., Geleta, T., Chiche, W., Rubyogo, J-C., Akpo, E., Ojiewo, C. O, (2021). Enhancing Chickpea production and productivity through stakeholders innovation plant from approach in Ethiopia. Learning from the TLIII project expreience in sub saharan Africa and south Asia, Springer, pp 97-111. 